\title{
熱測定で見るタンパク質の高次構造 田中晶善
}

タンパク質の変性に伴う熱の吸収を精密測定することにより，タンパク質分子の“かたち”，すなわちドメイン 構造，オリゴマー形成状態，およびリガンド結合によるそれらの变化などに関する知見が得られる. これを $\mathrm{X}$ 線 結晶構造解析などの結果と併せ用いることにより，タンパク質分子の構造と機能について総合的な理解が可能と なる. その具体例のいくつかを紹介する.

酵素などの球状タンパク質では，分子内に複数 のドメインがあり，それぞれのドメインが異なっ た機能を持つ場合がしばしばある。また，複数の 分子が集まって機能を発揮する場合も多い. ドメ インは「分子進化」といら視点からも興味深い対 象である.

解糖系の初発反応を触媒する醳素であるへキy キナーゼには大小 2 つドメインがある. そ礼ら を隔てる深い溝に，基質の 1 つであるグルコース が結合すると，グルニースを包み込むように2つ のドメインが閉じることが，X線結晶構造解析か ら知られている。

図 1 はへキソキナーゼが熱変性する様子を, 断熱型示差走査熱量計 (adiabatic differential scanning calorimeter, 以下 DSC) によって観測 したものである(1). 一定の速さで低温側から徐々 に温度を上げていったときの比熱の変化を記録し ており，変性が起こる温度付近では，変性反応に 要する熱をタンパク質が余分に吸収するため，比 熱が通常より大きくなる. その比熱のピーク位置 から频およその変性温度が知られる。

図 1-A 注遊離のへキソキナーゼの場合である. 変性温度を異にする 2 つピークが観測され，2 つのドメインがそれぞれ独立に変性する様子が伺 われる。これにグルコースを加えると図 1-Bの ように単一のピークしか観測されず，分子全体と して変性していることがわかる。これはX線結晶 構造解析の結果と符合しており, 構造的なドメイ

High-order Structure of Proteins Revealed by Calorimetry

* Akiyoshi TANAKA, 三重大学教育学部化学教室

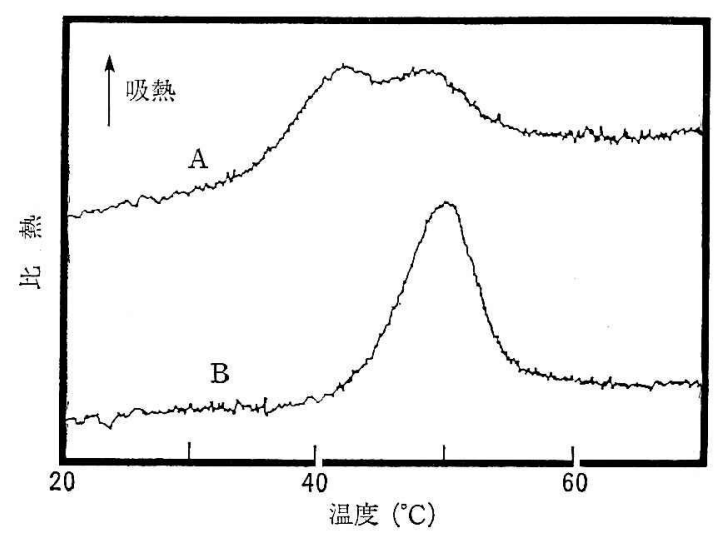

図 1⿴E.coli のへキソキナーゼ (単量体) の DSC 曲線 文献 1 の図 2 に基づいて旅粋. 遊離の酵萃 (A), および $100 \mathrm{mM}$ グルュース共存 (B) の場合. $\mathrm{pH} 8.5$, 無塩.

ンと変性反応の挙動単位とがよく対応していると 言えよう。

DSC は，熱変性なぞの相転移に伴う比熱の 変 化を測定する装置であるが，上記のように DSC 曲線はタンパク質の高次構造を反映して括り， DSC の結果から高次構造を推測できることも多 い. 熱測定は熱力学量が直接に求められる点で重 要であるが，特に DSC はその精度の高さと理論 的背景の確かさからたとえばアミノ酸置換によ る変性の熱力学量への効果を定量的に調べ, タン パク質の構造安定性に寄与する因子を解析するこ とに積極的な役割を果たしている(2,3). 本稿では， 球状タンパク質の高次構造との関連で DSC を用 いた研究例を紹介する. 


\section{DSC 測定の原理}

\section{1. 二状態転移モデル}

タンパク質は巨大分子であるが，その变性反応 は分子が徐々に汪ぐれていくのではなく，いった 几変性が始まると，その分子全体が一挙に変性す る.すなわち，基本的には天然のコンパクトな立 体構造を保った分子種 $\mathrm{N}$, その構造が壊れて変 性した分子種Dの 2 つの状態のらちの 1 つだけを とる*1.

タンパク質の熱変性では，ゆで卵のような不可 逆な熱変性を連想しがちだが，これは変性した分 子の会合などが原因であって，変性反応は独立し た素過程としては本質的には可逆である，事実， 熱変性させた試料を冷却すると天然の構造に巻き 戻る例が，特に球状小型タンパク質で多く知られ
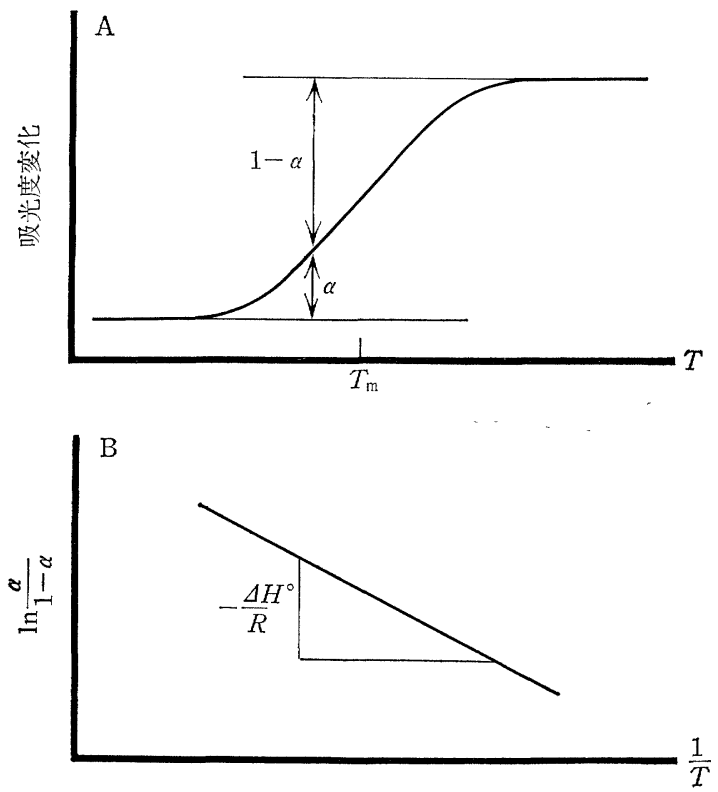

ている.

$\mathrm{N}$ とDの間には次のような平衡が成り立つ.

$$
\begin{array}{ll}
\mathrm{N} \stackrel{K, \Delta H}{\rightleftharpoons} & \mathrm{D} \\
\Omega & \Omega
\end{array}
$$

$K$ は平衡定数で, $K=[\mathrm{D}] /[\mathrm{N}]$ である. 変性 反応の進行度 $\alpha$ を用いると $K=\alpha /(1-\alpha)$ である。 また $\Delta H$ は変性反応に伴らェンタルピー変化，つ まり一定圧力の条件下で変性反応を起こすのに必 要な熱量である。直感的に言えば，ゆで畉を作る のに必要なガスの量に対応する.

一般に，分子量が 2 万ないし 3 万程度以下の小 型球状タンパク質の変性は, 式 1 の「all or none モデル」あるいは「二状態転移モデル」で説明で きることが多い，平衡反応であるから，式 1 につ いて van't Hoff の式が成り立つ。
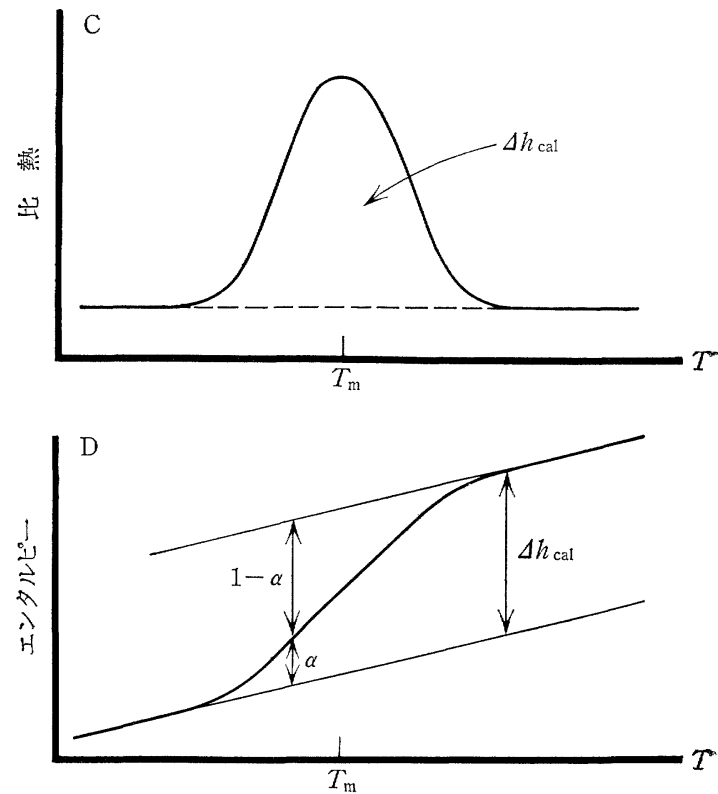

図 2ロタンパク質の熱変性に伴う吸光度の変化 $(\mathrm{A})$ ，比熱の変化 $=\mathrm{DSC}$ 曲線（C），およびグラムあたりのエンタ ルピーの変化 (D)

横軸はいずれも温度、Bは，AまたはDに基づく van't Hoff プロットＣとＤは微分・積分の関係にある。

*1 「温度が上がるにつれてタンパク質の構造が徐々に洼どけるように思われる. 変性温度の範围内では，構造の一部は保存され，一 部は壞れている」(バーロー『生命科学のための物理化学』第 2 版，野田春彦訳，東京化学同人，p. 50)。これは図4のような DSC 曲線を解説した記述の一部であるが，これが個々の分子を念頭に和いたものであれば誤りである. 1個の分子に着目した場合, 天然状 態 $\mathrm{N}$ か変性状態 Dかのいずれかであって，温度変化ととるに“構造が徐々に洼どける”のではない，徐々に変化していくのはマク口

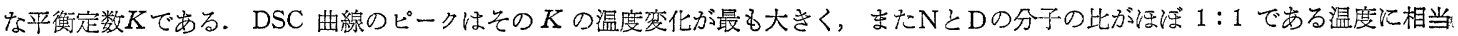
する.

な妨最近，変性や再生反応の中間体としての「モルテン・グロビニール」についての研究が進えでいるが，上記の教科書の記述とは 直接には無関係である。モルテン・グロビュールについての詳細はたとえば文献(4)，およびそこに引用されている文献を参照された W. 


$$
\frac{\mathrm{d}(\ln K)}{\mathrm{d}(1 / T)}=-\frac{\Delta H^{\circ}}{R}
$$

$R$ は気体定数, $T$ は絶対温度である.

タンパク質の変性は，たと光ば吸光度や螢光の 変化として観測される，そこで温度変化に対する その変化量を記録し(図 2-A)，そこから変性反 応の進行度 $\alpha$ を求めて平衡定数 $K$ を得, その自然 対数 $\ln K$ をの逆数 $1 / T$ に対してプロットする と，その傾きから $\Delta H^{\circ}$ を求めることができる（図 2-B). 熱測定によらず，このようにして平衡定数 Kの温度変化から間接的に求められたエンタルピ 一変化を van't Hoff のエンタルピー変化といい, $\Delta H_{\mathrm{vH}}$ で表わす(単位は $\mathrm{J} \cdot \mathrm{mol}^{-1}$ ). これは “ 1 モ ル”のタンパク質を変性させるのに必要な熱量を 表わす.

一方, DSC によって熱変性反応に伴らタンパ ク質の比熱の変化とエンタルピー変化を直接測定 することができる、溶媒である水は比熱が大き く，その比熱の海の中に $0.1 \sim 1 \%$ 程度しか存在 していないタンパク質の比熱の変化を正確に測定 するのは容易ではなく，ちょらど高層ビルの屋上 に立っている人が背伸びしたとさの身長の変化を 地上から正確に測定するのに似た困難が伴う．そ のため, DSC 装置には精密測定のための 種々の 工夫が凝らされている，装置の詳細は文献 ${ }^{(5,6)} に$ 詳しく解説されている.

熱変性反応は吸熱反応であるから，変性反応が 起こる温度範囲においては溶液中のタンパク質の 比熱が異常に大きくなる，その比熱変化を記録し たものが DSC 曲線であり，図 2-C のような結 果が得られる.DSC 曲線とベースラインに团ま れた面積は変性反応を行なわせるために系に余分 に加えた熱量である.このようにして，熱測定か ら直接に得られたエンタルピー変化をカロリメト リックなエンタルピー変化といい, $\Delta h_{\text {cal }}$ で表わ す(単位は $\mathrm{J} \cdot \mathrm{g}^{-1}$ ). これに分子量 $\mathrm{M}$ をける と，1モルあたりのエンタルピー变化， $\Delta H_{\mathrm{cal}}$ が 得られる。

一方, DSC 曲線はエンタルピーの 温度依存性 （図 2-D）を温度で微分したものに対応し，温度 変化に伴う平衡定数の変化を測定していることに
もなるので, DSC 曲線からは $\Delta H_{\mathrm{cal}}$ のほかに $\Delta H_{\mathrm{vH}}$ も同時に求めることができる.

\section{2 種類のエンタルピー変化}

ここで, $\Delta H_{\mathrm{vH}}$ と $\Delta H_{\mathrm{cal}}$ という 2 種類のエン タルピー変化が得られたが，タンパク質の熱変性 反応が式 1 に従ら限り両者は一致する。逆に言光 ば，測定原理を異にするこれら 2 つのエンタルピ 一変化の比が 1 であれば，その熱変性反応が二状 態転移（式 1）であることの実験的根拠となる. DSC 装置の設計者でもある Privalov は $\alpha$-キモ トリプシンをはじめとした 5 種の小型球状タンパ ク質の熱変性を種々の $\mathrm{pH}$ で測定して $\Delta H_{\mathrm{vH}} /$ $\Delta H_{\text {cal } 1}$ の值を求め, 総計 52 点の平均值として $0.95 \pm 0.03$ という，きわめて 1 に近い值を得て いる(7).

これに対し，たと壳ば分子が二量体を形成して 変性反応をする場合,

$$
\mathrm{N}_{2} \rightleftharpoons \mathrm{D}_{2}
$$

を考えると，平衡定数として観測されるのは $\mathrm{N}_{2}$ と $\mathrm{D}_{2}$ との間の平衡に基づくものである.つま り，挙動単位である $\mathrm{N}_{2}$ と $\mathrm{D}_{2}$ それぞれを見かけ の 1 分子と考えている. 平衡定数の温度依存性か ら式 2 にって $\Delta H$ が求められるが, その単位, $\mathrm{J} \cdot \mathrm{mol}^{-1}$ の “ $\mathrm{mol}^{-1} ”$ は，見か汀の 1 分子の 1 乇 ル,つまり二量体 1 モルあたりである. しかし, 平衡定数 $K$ 観測や，van't Hoff のプロット自体 からはそのことはわからない， $\Delta H_{\mathrm{vH}}$ が，乙ばし

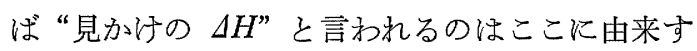
る.

これに対し，熱測定からは 1 グラムのタンパク 質の変性に要する熱量 $\Delta h_{\mathrm{cal}}$, 和よびこれに分子 量をかけた単量体 1 モルあたりの “真の $\Delta H ”$, $\Delta H_{\mathrm{cal}}$ が直接に求められる. 変性反応が式 3 に従 う場合, 2 つのエンタルピー変化の比, $\Delta H_{\mathrm{vH}} /$ $\Delta H_{\text {cal }}$ は 2 となる (図3参照).このように, $\Delta H_{\mathrm{vH}} / \Delta H_{\text {cal }}>1$ は分子間の正の相互作用を表わ す. $\Delta H_{\mathrm{vH}}$ を $\Delta h_{\mathrm{cal}}$ で割った值は「挙動単位の分 子量」と呼ばれる。これは“見かけの 1 分子”の 分子量であり, 式 3 で言光ば $\mathrm{N}_{2}, \mathrm{D}_{2}$ の分子量で ある. 逆に $\Delta H_{\mathrm{vH}} / \Delta H_{\mathrm{ca} 1}<1$ である場合は，分子 


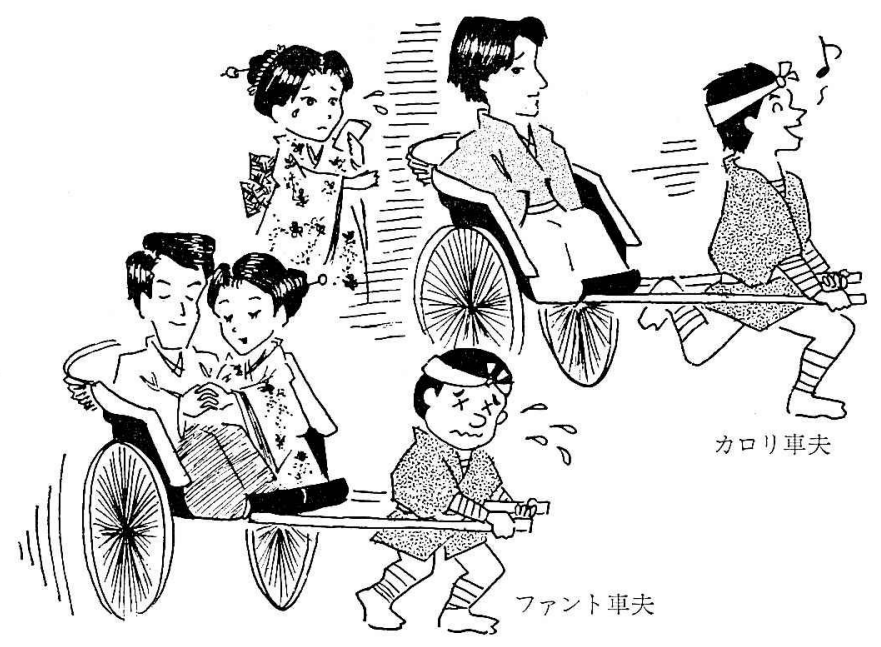

図 3曰乗客の体重（たと光ば $60 \mathrm{~kg}$ ）に基ついてー人を 1 単位と見なすカ口 リ車夫と“ひとまとまりの行動単位”を 1 単位と見なすファント車夫

乗客間に“正の相互作用”がある場合，同じ“1 単位”でも，ファント車夫はカロリ車 夫よりる疲れる. 2 人の車夫の疲れ方を比較すれば，“行動単位”の人数（この場合は 2 人)がわかる.

内に複数のドメインが存在し，それぞれが二状態 転移の変性反応を起こすような場合に対応する。 その逆数, $\Delta H_{\mathrm{cal}} / \Delta H_{\mathrm{vH}}$ は当然 1 より大きいが, この值は，1分子が実際に何分子としてふるまう かを示す值と見なせる。

前出のへキソキナーゼのように，分子内に $\mathrm{A}$, B 2つのドメインがあってとれぞれが独立に変性 する場合，父の变性反応山，

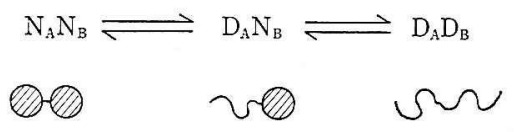

のように表わされる. 分子種 $\mathrm{D}_{\mathrm{A}} \mathrm{N}_{\mathrm{B}}$ は, ドメイ ンAが変性し，ドメイン Bが構造を保持している ものである.

*2式 5 は， $\Delta h_{\mathrm{cal}}$ が同じでも，DSC 曲線がシャープになるほ ぞ $\Delta H_{\mathrm{vH}}$ の值が大きくなることを示している. したがって，一 般に分子量の大きいタンパク質は小さいものに比べ DSC 曲線 が鋭くなる。

高分子ではないが，その極端な例は水が水になる現象である. 温度と比熱の関係を衣わすグラフでは，比熱は $0^{\circ} \mathrm{C}$ といら一点 において無限大澄散し，しかも面積を積分すれば $334 \mathrm{~J} \cdot \mathrm{g}^{-1}$ $\left(80 \mathrm{cal} \cdot \mathrm{g}^{-1}\right)$ という有限の融解熱 $\left(\Delta h_{\mathrm{cal}}\right)$ が得られ，ディラッ クの $\delta$ 関数の上うな挙動を示す. したがって, 武 4 に従党ば $\Delta H_{\mathrm{vH}}$ は無限大でありこれを $\Delta h_{\mathrm{cal}}$ で割った值，「挙動単位 の分子量」も無限大となる.つまりコップ 1 杯の水全体が巨大 な1分子としてふるまら。
図 1-A のヘキソキナーゼの 例のように, 2つの変性温度が 離れている DSC 曲線からは, 複数のドメインがあることは一 見して明らかであるが，变性温 度が近いと単一のピークとし て観測される. 後者の場合で も, $\Delta H_{\mathrm{vH}} / \Delta H_{\mathrm{cal}}<1$ となり, 式 1とは区別されるが，それぞ れのドメインに注目すれば，や はり二状態転移であって, 各温 度で式 4 の平衡が成り立ってい 万.

DSC 曲線のピーク温度 $T_{\mathrm{m}}$

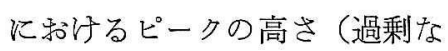
比熱の大きさ）を $c_{\max }$ とする と, $\Delta H_{\mathrm{vH}}$ と $\Delta h_{\mathrm{cal}}$ は次のよう な関係にある。

$$
\Delta H_{\mathrm{vH}}=4 R T_{\mathrm{m}}{ }^{2}\left(c_{\max } / \Delta h_{\mathrm{cal}}\right)
$$

詳細な解析の前に, DSC 曲線の下側の面積を 測って $\Delta h_{\mathrm{c} 11}$ を求め, またピークの高さを求めれ ば $\Delta H_{\mathrm{vH}}$ が求められる*2. 通常, 二状態転移か否 かを判定するには，複数の分光学的手法を併用 し，それらを比較することにより行なわれるが， DSC では上記のように“グラフ用紙と物差し” で簡単に判定できる。ささらに詳細な DSC 曲線の 解析を行なうことにより，種々の有用な知見が得 られる.具体的な方法を詳しく解説したすのとし て, 文献 ${ }^{(5,6,8)}$ 和よびそれらに引用された文献を参 照していただきたい。

\section{単純な二状態転移 $(\mathbf{N} \rightleftharpoons \mathbf{D})$ の例}

\section{リゾチーム}

図４はＴ４ファージ・リゾチームのアミノ酸 置換タンパク質の 1 つついて，熱変性反応を観 測した例である ${ }^{(9)}$.この変異型タンパク質や，野 生型の場合も含め, $\Delta H_{\mathrm{vH}}$ と $\Delta H_{\mathrm{ca} 1}$ の比は 1 とな り，熱変性が $\mathrm{N}$ と D 二状態転移であることを示 している.

不可逆な熱変性を起こすタンパク質では，試料 を一旦高温まで走査した後，低温に戻しても天然 


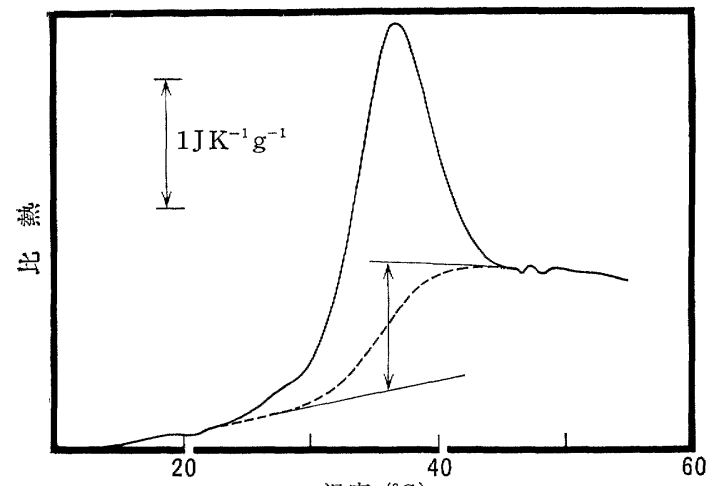

温度 $\left({ }^{\circ} \mathrm{C}\right)$

図 4 m T 4 ファージのリゾチーム (Cys 54 $\rightarrow$ Thr +Cys 97 $\rightarrow$ Ala 置換型) の DSC 曲線

文献 9 の図 1 亿基づいて改变. $\mathrm{pH} 2 . \downarrow$ 梳性の前後での比熱 の差 $\Delta c_{\mathrm{p}}$. 破線はペースラインで，これは $\Delta h_{\mathrm{cal}}$ を0 と仮定し た場合の仮想的な DSC 曲線に相当する. DSC 曲線とベースラ インで国まれた面程から $\Delta h_{\mathrm{cal}}$ が評価できる。

構造は戻らず，したがって，再走査してもベース ライン状の DSC 曲線しか得られないが, リゾチ 一ムの場合は再走査すると初めの DSC 曲線と同 一の結果が得られる.したがって、リゾチームの 熱変性は可逆反応である. また，DSC では 1 分 あたり $1^{\circ} \mathrm{C} て ゙$ 昇温させながら走査することが多い が，その走查速度を变えても結果は变わらない。 これらのことから, リゾチームの場合は, 測定し ている各温度で式 1 の平衡が完全に成り立ってお り, 式 2 に基づいた平衡論熱力学的解析をするこ との妥当性が実験的に保証されたことになる.

図 4 では変性反応の 前後のベースラインに 差 （れ）があり（変性の前後での比熱の差 $\left.\Delta c_{\mathrm{p}}>0\right)$, 変性タンパク質は天然構造よりも比熱が大きいこ とを示している．これはほとんどのタンパク質の 熱変性で観測されており, 主として疎水性アミノ 酸が溶媒の水へ露出することに起因すると考兄ら れている. $\Delta c_{\mathrm{p}}$ がゼロでないことは変性の熱力学 量の温度依存性に大きく影響し，変性のギブズ自 由エネルギー変化*3が, 高温側のみならず, 低温側 でもマイナスの值を取り得ることが予想される. つまり通常の熱変性（高温変性）の他に，温度を 下げることによってもやはり高次構造が壊れるこ

*3 変性のギブズ自由エネルギー $\Delta G^{\circ}=-R T \ln K$ で, この 值が正であるほどN 状態が安定となる，負ではD状態が安定と なる.
と(低温変性)が理論的に予測され，ミオグロビン をはじめ，いくつかの実験例が報告されている. たと光氷結しなくとも，低温にして和汗ばタンパ ク質は安定であるというのは必ずしも正しくない。

\section{分子内に複数のドメインを持つタンパク質}

\section{入リプレッサー}

分子内ドメインが独立に変性する顕著な例の一

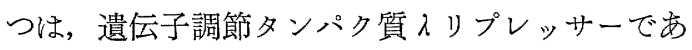
る. その野生型タンパク質の DSC 曲線 ${ }^{(10)}$ (図 5, wild type）は, 約 $20^{\circ} \mathrm{C}$ も離れた 2 つのピークを 持つ. 低温側がN末端側のドメイン（オペレータ 一 DNA 結合ドメイン), 高温側が C 末端側のド メインの熱変性にそれぞれ対応する.

ここで面白いのは，N末端側ドメインに属する アミノ酸残基を別のアミノ酸に置換した場合であ る. 図 5 に示すように， $\mathrm{N}$ 末端側ドメインはアミ ノ酸置換によって安定性に変化が起こり, 低温側 のピーク温度は大きく変化する. しかし, 高温側 のピーク温度には汪とんど変化がない。

このことは,アミノ酸置換によってN末端側ド メインの構造に变化が起こってもC末端側には影

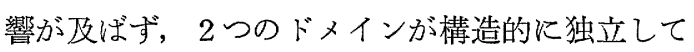
いることを示している. C末端側ドメインの欠落 した， N末端側ドメイン単独（アミノ酸残基 1〜

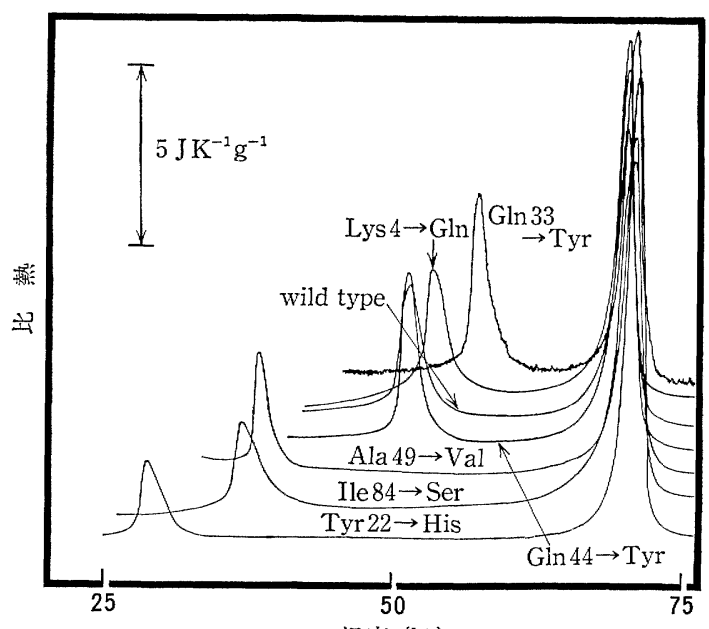

温度 $\left({ }^{\circ} \mathrm{C}\right)$

図 $5 n \lambda$ リプレッサーの DSC 曲線(10)

野生型 (wild type) およびこれにアミノ酸置換を加えた種々の 変異型タンパク質の例. $\mathrm{pH} 8$. エール大学 Sturtevant 教授提 供の原図に基つ゚いて抜粋. 
92 のみ)の DSC 曲線は，全タンパク質を用いた 場合の対応するDSC 曲線（図 5 低温側）と活涪

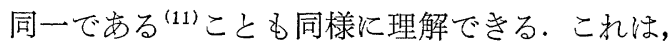

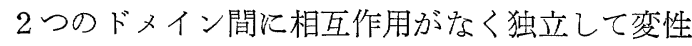
する例であるが，これは先しろ例外に属し，一般 にはドメイン間には相互作用がある。

\section{グルコアミラーゼ}

澱粉をグルコースに加水分解する酵素である Rhizopusのグルコアミラーゼ(12) の場合, DSC 曲 線は単一ピークであるが，変性温度がわずかに異

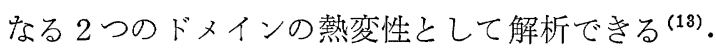
グルコアミラーゼの強力な阻害物質である SGI (1-deoxy-1,5-diamino glucopyranose) をこれに 加えると, DSC 曲線は単一のピークのまま全体 に高温側にシフトする. この結果の解析から, 次 のことが判明したすすなわち SGI は，2つのド メインのらら高温で変性する側に結合して，この ドメインの変性温度をより高温側にシフトさせる こと、および低温側ドメインにはSGI は結合しな いが，2つのドメイン間に正の相互作用があり，そ の結果, SGI が高温側に結合すると低温側のドメ インの変性温度も高温側にシフトするのである ${ }^{(13)}$.

これは, 次のような解析に基づいている。種々 の濃度の SGI 共存下で測定した DSC 曲線から， これら 2 つドメインの熱変性に関する $\Delta H_{\mathrm{vH}}$ がそれぞれ求められる. 一方，SGI 共存下での 各ドメインの変性温度の逆数に対して, SGI 初 濃度の対数をプロットすると，その直線の傾きか ら，やはりそれぞれのドメインの $\Delta H_{\mathrm{vH}}$ を求め ることができる、これら 2 つ方法で評価した $\Delta H_{\mathrm{vH}}$ を比較すると，高温側のドメインでは両者 がよく一致するが，低温側ではまったく一致しな かった.このことは, 高温側ドメインへの SGI の結合のみが，物理的実体を伴った解釈可能なも のであることを示している.

Aspergillus のグルコアミラーゼでは，2つのド メイン，つまり触媒ドメインと澱粉結合ドメイン が存在することが報告されている. 上記の $R h i$ zopus のグルコアミラーゼでも同様の構造が期待 できるとすれば, SGIが結合する高温側ドメイン が触媒ドメイン，低温側が基質結合に関与する基
質結合ドメインである可能性が示唆される.

\section{CAP}

カタボライト活性化タンパク質 (CAP) は, 分 子内に大小 2 つのドメインを持つことがX 線結晶 構造解析から認められ，cAMP はその大きいほ らのドメイン（ $\mathrm{N}$ 末端側）に結合する. CAP 単独 の DSC 曲線(14) は単一のピークを持ち, $\Delta H_{\mathrm{vH}} /$ $\Delta H_{\text {cal }}$ は 2 に近い. このことは, CAP が通常二 量体として存在することと符合し, 変性反応は前 述の式 3 で表わすことができる.

これに対し，CAP に cGMPを結合させた場合 は，低温側に肩を持つような DSC 曲線が観測さ

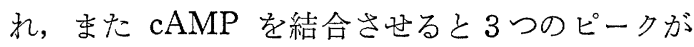
観測される.これらはそれぞれ，2つ款よび $3 つ$ のドメインの変性として解析することができる. つまりこの場合は，ヘキソキナーゼとは逆に，り ガンド結合によってドメインの挙動が分離される 例である。

$\mathrm{CAP} へ$ 結合様式の違いによって, ヌクレ

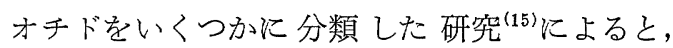
cGMP は CAP の構造にほとんど影響を与えな いのに対して， cAMP は分子全体に構造変化を ひき起こしている，DSC に和ける挙動の違いは， ヌクレオチド-CAP 複合体に和ける構造の違いを 反映しているものと考えられる.

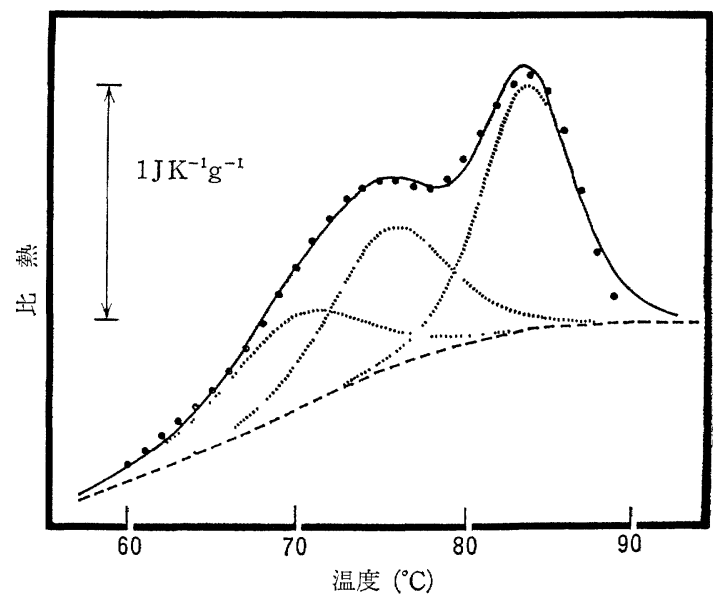

図 6"アーモンド $\beta$-グルコシダーゼの DSC 曲線(16) 理論曲線と比較するため, 困では黒丸で表わしてある. pH 6.

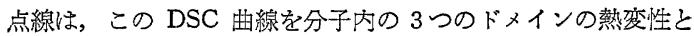
して分解した理論曲線. 実線はその 3 つの理論曲線の和. 破線 はベースライン. 


\section{$\beta$-グルコシダーゼ}

セルラーゼの一種であるアーモンドの $\beta$-グル

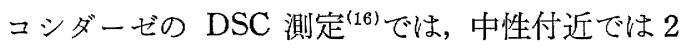
つのピークが観測され, 分子内に複数のドメイン を持つことが明らかである. 解析の結果, 分子内 に3つのドメインがあることが判明した（図 6).

ところが，酸性側では DSC のピークが1つしか

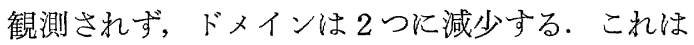
$\mathrm{pH}$ の変化によって, すなわち $\mathrm{H}^{+}$といらリガン ドの特異的な解離・会合によって，タンパク質分 子の構造が変化することを示している.

マルチドメインタンパク質の DSC 測定の例は 他にも多いが，さらに达み入った系を解析してい るものとして, Privalovによる総説 ${ }^{(17)}$ がある. ペ プシノーゲンの 2 つのドメインの $\Delta h_{\mathrm{cal}}$ を, 110 ${ }^{\circ} \mathrm{C}$ での值に換算して比較することにより，各ド メインの「部分分子量」を評価し, 別途求められ ている值とよく一致する結果を得た，という面白 い例も紹介されている。 これは， $110^{\circ} \mathrm{C}$ 付近では タンパク質の “個性”が失われ， $\Delta h_{\text {ea } 1}$ が一定值 をとることに基づいている.

\section{多量体を形成するタンパク質の例}

\section{プロテアーゼインヒビター}

Streptomyces のプロテアーゼインヒビター SSI は, 常温で二量体を形成している. その DSC 曲 線のピークは，濃度の増大とともに高温側にシフ トする ${ }^{(18)}$. これは SSI の熱変性が解離を伴うこ とを示しており, 次の式に従って解析できる.

$$
\frac{1}{2} \mathrm{~N}_{2} \rightleftharpoons \mathrm{D}
$$

類似の例として, クロラムフェニコールアセチ ルトランスフェラーゼがあり ${ }^{(19),}$ この場合, 相同 な 3 つの゚ロトマーが変性反応とともに解離す る.

\section{ヌクレアーゼ}

図7は Staphylococcus のヌクレアーゼのアミ ノ酸置換タンパク質の 1 つついて, 種々の濃度 で DSC 曲線を得た例である.この場合， $\Delta H_{\mathrm{vH}} /$ $\Delta H_{\text {cal }}$ は 1 より大きくなり, 分子間相互作用が存 在していることを示している. SSI の例とは逆

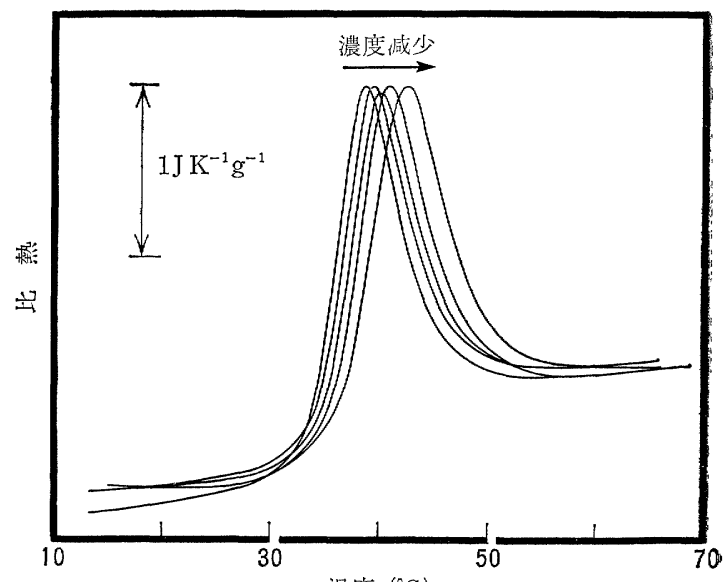

温度 $\left({ }^{\circ} \mathrm{C}\right)$

图 7 Staphylococcus のヌクレアーゼのアミノ酸置 換タンパク質 Ala $90 \rightarrow$ Ser の DSC 曲線とその濃度依 存性

濃度は左から右へ, $23 \mathrm{mg} \cdot \mathrm{ml}^{-1}$ から $4.3 \mathrm{mg} \cdot \mathrm{ml}^{-1}$ まで順次減少 している、縦軸は比熱，すなわち単位質量あたりに换算した熱 容量であるので, 濃度によらずピーク高さは変わらない. $\mathrm{pH} 7$.

に，濃度が高くなるとともにピーク温度が低温側 にシフトすることから，この場合は变性に伴っ て多量体化（二量体化）が進行することがわか る ${ }^{(20)}$. た, ヌクレアーゼの野生型および種々の 変異型タンパク質が同じ挙動を示して和り ${ }^{(20)}$ ，拉 扣よと次式が成り立つ。

$$
\mathrm{N} \rightleftharpoons \frac{1}{2} \mathrm{D}_{2}
$$

変性に伴う多量体化という場合ゆゆで卵のよう な不可逆变性を連想しがちであるが， ヌクレアー ゼの場合は完全に可逆的で, 再走査をしてもまっ たく同じ DSC 曲線が再現される.

な㧍，多量体化の問題からはそれるが， ヌクレ アーゼで興味深いのは, 全アミノ酸 149 残基のう ち，C末端側の 13 残基を欠落させた“フラグメ ント”の場合である. この 13 残基は三次構造上 でも分子の端にあり，活性中心を形成しているわ けでもなく, 一見, 重要とも思われない部分であ る.ところがこれを欠落させたフラグメントの DSC 曲線ではまったくピークが見られず，常温 に拈いてすで沉高次構造が失われている・ところ がこれに対し，一次構造上では中心付近にあるア ミノ酸 6 残基, Thr 44 から Lys 49 を欠落させ たフラグメントでは, 全タンパク質と泳涪同じ 
DSC 曲線が観測される.

これらのことから，タンパク質の高次構造を保 持する要因はかなり複雑であり，部分的要素の寄 せ集めではないと言えよう。酵素利用技術に関す る 1970 年頃の文献では，酵素の活性中心だ汓を 取り出すことが 80 年代初頭にもできるようにな る，と書か机ているものもあるが，あまりに楽観 的な予想であった，一見無駄に見える部分が “役 《立つ”部分を支えている場合がある——むし ろ，一般的と言うべきだろう。

以上, 高次構造との関連で DSC を用いた研究 のいくつかについて紹介した，上記のように，高 次構造が既知のタンパク質であれば，より総合的 な理解が得られるが，未知の場合でも熱測定だけ 飞基づいて高次構造をある程度予測することが可 能である、熱測定はその本質上，現象論的な面の あることを免れないが, 測定機器や解析理論の進 歩によって, タンパク質の高次構造に関しても, 有用な, 熱測定でしか得られない詳細な知見が得 られるようになってきた。

DSC 測定は精製タンパク質が 2 〜 3 シグラム あれば少なくとも 1 回の測定ができる（現在開発 中と聞く, さらに高感度な DSC 装置では, 必要 量は1桁低くなるだろら). そしてその単純に見 える1本の DSC 曲線から多彩な情報を掘り起 こすことができる１１本のスキャンを取るのに 2 時間程度 (以上) 必要だが, こういうのんびりし た時間のスパンも熱測定の意外な魅力かも知れな い.

草稿にご意見・ご助言を賜りました京都大学外村辨一郎先 生, 大阪府立大学高橋克忠先生, 深田怡る久先生汇深謝いたし ます, 図 3 は三重大学教育学部化学科学生大矢真弓さんの手に なるものです.

\section{文献}

1) K. Takahash1 \& J.M. Sturtevant : Biochemistry, 20, 4693 (1981).

2) 油谷克英：生物物理， 32, 27 (1992).

3) 田中晶善, 北村進一：生物物理，32，110 (1992).

4）油谷克英，中村春木：“蛋白質工学”，朝倉書店， 1991, p. 60 .

5) J.M. Sturtevant: Ann. Rev. Phys Chem., 38, 463 (1987).
6) 高橋克忠 : 蛋白質 核酸酵素，33，337 (1988).

7) P. L. Privalov \& N. N. Khechinashvil $: J$. Mol. Chem., 86, 665 (1974).

8）城所俊一，和田昭充: 蛋白質核酸酵素，33，348（1988）

9) C. Hu, S. Kitamura, A. Tanaka \& J. M. Sturtevant : Biochemistry, 31, 1643 (1992).

10) M. H. Hecht, J. M. Sturtevant \& R. T. Sauer : Proteins: Struct., Funct., Genet., 1, 43 (1986).

11) R.S. Stearman, A. D. Frankel, E. Freire, B. Lui \& C O.Pabo: Biochemistry, 27, 7571 (1988).

12) K. Hirom1, M. Ohnish1 \& A. Tanaka: Molec. Cell Biochem., 51, 79 (1983).

13) A. Tanaka: Netsu Sokutei (Calorimetry and Thermal Analysis), 18, 77 (1991).

14) L. R. Ghosami, A. M. Brown \& J.M. Sturtevant : Biochemistry, 27, 5257 (1988).

15) R. H. Ebright, S. F. J. LeGrice, J. P. Miller \& J. S. Krakow: J. Mol. Biol., 182, 91 (1985).

16) A. Tanaka: Agric. Biol. Chem., 55, 2773 (1991).

17) P. L. Privalov: Adv. Protein Chem., 35, 1 (1982).

18) K. Takahash1 \& J.M. Sturtevant: Biochemistry, 20, 6185 (1981).

19）端谷隆文，山本昌英，蒜田省三，深田はるみ，高橋克忠： 㦁化誌, 66，348 (1992).

20) A. Tanaka, J. M. Flanagan \& J. M. Sturtevant : Protein Science, 2, 567 (1993).

\section{研究員公募}

\section{三菱化成生命科学研究所特別研究員}

三菱化成生命科学研究所第 5 プロジェクトで灶特別研究員 (postdoctoral fellow) を1名募集しています。.

資 格: 博士号取得者, またはそれ相当する研究業績があ り，分子生物学の素盖のある者.また，すぐ着任可能であ ることが望ましい。

研究テーマ:ショウジョウバェ本能行動の分子生物学（同性愛 行動の原因遺伝子クローニングなど)

期 間 : 採用日から 1 年ごとの更新により $2 \sim 3$ 年間

応募方法 : 履歴書, 研究業績目録, 推鹤書を添兄て下記に送付 のこと.

照 会 先: ₹194 東京都町田市南大谷 11 三菱化成生命科学研究所

第 5 プロジェクト 山元大輔

Tel. 0427-24-6299, Fax. 0427-29-1252 